\title{
Rośliny lecznicze z komponentem kolorystycznym w polskim i niemieckim językowym obrazie świata
}

\author{
Izabela Bawej \\ Uniwersytet Kazimierza Wielkiego, Bydgoszcz \\ iza_bawej@ poczta.onet.pl
}

\begin{abstract}
Streszczenie
Niniejszy artykul poświęcony jest semantyczno-kulturowej interpretacji nazw ziół $w$ polskim $i$ niemieckim językowym obrazie świata. Jego celem jest opis porównawczy nazw gatunkowych roślin leczniczych z komponentem barwy. Określenia takie sa bogate znaczeniowo, przekazuja nie tylko informacje o wartości i funkcji koloru w codziennym życiu, ale pokazuja również, w jaki sposób ludzie w danej kulturze postrzegaja, uwydatniaja $i$ wartościują elementy otaczajacej ich rzeczywistości pozajęzykowej. Nomenklatura fitoterapeutyczna z elementem kolorystycznym jest bowiem produktem określonej kultury, łaczacym $w$ sobie elementy codziennego życia użytkowników danego języka, odzwierciedlającym tradycje, zwyczaje oraz sposoby myślenia członków danego narodu o rzeczywistości pozajęzykowej. Przedmiotem analizy jest materiat egzemplifikacyjny pochodzacy ze źródet leksykograficznych. Z badania wynika m.in., że językowy obraz nazw roślin leczniczych zależy nie tylko od wygladu rośliny, jej walorów smakowych, wartości czy mocy, ale również od potrzeb $i$ wybranych skojarzeń danej zbiorowości językowej, a największa reprezentację $w$ nazwach ziót znalazły barwy 'biała' $i$ 'czarna'
\end{abstract}

Słowa kluczowe: zioła, kolor, rzeczywistość, analiza, podobieństwa, różnice

Abstract

Medical Plants with Colour Terms in the Polish and German Picture of the World

In the paper I focus on the problem of a contrastive description of medicinal plants with colour terms in the Polish and German linguistic picture of the world. The article discusses the question of what people think about the world and its elements on the base of herbs. Colours in the botanical nomenclature express some social contents, they are signs, have value and convey information about reality in two languages. They result from a complex set of circumstance e.g. traditions, habits, ways of life, experiences and the mentality of Poles and Germans. The contrastive description demonstrates also that the most plants have in both languages the names with 'white' and 'black'.

Keywords: medicinal plants, colour, reality, analysis, similarities, differences 


\section{Wstęp - informacje ogólne}

Analizy porównawcze są bardzo produktywnym obszarem badań nad językami. Warto i należy poznawać podobieństwa i różnice między własną a inną kulturą, między własnym a innym językiem w różnych obszarach rzeczywistości pozajęzykowej. Rozległa tematyka $\mathrm{z}$ tego zakresu prezentowana $\mathrm{w}$ literaturze przedmiotu sprawiła, że dokonałam selekcji i wyboru problematyki badawczej. Celem niniejszego artykułu jest porównanie wybranego fragmentu otaczającego świata, jakim jest pole semantyczne nazw roślin leczniczych w języku polskim i niemieckim, a prezentowany opis porównawczy został zawężony do roślin leczniczych z elementem kolorystycznym w nazwach gatunkowych ${ }^{1}$.

Przez wiele lat leki naturalne, zwłaszcza rośliny lecznicze, były jedynym sposobem zwalczania chorób. Pomimo rozwoju przemysłu farmaceutycznego i produkcji leków chemoterapeutycznych nie zrezygnowano całkowicie z roślin leczniczych i lekarstw, które można z nich otrzymać. Wiele właściwości ziół, np.: wartość dietetyczna w różnych kuracjach, zawarte w nich elementy, jak witaminy, substancje antybakteryjne, antywirusowe lub antyrakowe, przyczyniły się do popularności roślin leczniczych. Często stosuje się je jako środek współdziałający z preparatami chemicznymi lub antybiotykami, a lekarze, farmaceuci i sami chorzy interesują się ich działaniem, zastosowaniem i sposobem użycia w leczeniu różnych chorób (Volák, Stodola 1987: 6).

Za roślinę leczniczą uważa się każdą roślinę użytą przez człowieka lub zwierzę, w dowolnej postaci i w jakikolwiek sposób, która wywiera określone działanie farmakologiczne. Rośliny lecznicze mogą różnorodnie oddziaływać na organizm człowieka. Mają działanie uspokajające, wpływając bezpośrednio na ośrodkowy układ nerwowy, rozkurczowe, działając na mięśnie gładkie określonego narządu, działanie nasercowe, działanie obniżające ciśnienie krwi, działanie pobudzające wydzielanie soku żołądkowego, działanie hamujące wydzielanie soku żołądkowego, działanie przeciwbiegunkowe, działanie przeczyszczające, działanie przeciwpasożytnicze, działanie żółciotwórcze i żółciopędne, działanie moczopędne, działanie wykrztuśne, działanie przeciwkaszlowe, działanie napotne, działanie przeciwpotne, działanie przeciwcukrzycowe, działanie mlekopędne, działanie przeciwko drobnoustrojom oraz działanie toksyczne (Ożarowski 1995: 467-491).

\footnotetext{
${ }^{1}$ Wszystkie obiekty naturalne (np.: rośliny, zwierzęta, substancje naturalne: woda, ziemia, minerały) mają swój kolor, ale nie wszystkie nazwy elementów przyrody ożywionej i nieożywionej łączą się z nazwami barw, np.: krokus, kot, kwarc. Badaniu poddano te obiekty, w których nazwa barwy występuje w nazwie gatunkowej danej rośliny leczniczej przynajmniej w jednym języku, np. śliwa tarnina - Schwarzdorn.
} 
Rośliny stosowane w medycynie konwencjonalnej i ludowej mienią się różnymi barwami, które mogą być wyrażane $\mathrm{w}$ ich nazwach gatunkowych, np.: naparstnica żólta, ciemiernik czerwony, czarny bez. Ponieważ nomenklatura roślin leczniczych z elementem kolorystycznym stanowi ciekawą część językowego obrazu świata (JOS) każdego języka, niniejszy artykuł poświęcony jest semantyczno-kulturowej interpretacji nazw ziół w języku polskim w konfrontacji z językiem niemieckim. Nazwy roślin z komponentem barwy są bogate znaczeniowo, przekazują nie tylko informacje o funkcji koloru $\mathrm{w}$ codziennym życiu, lecz pokazują także, w jaki sposób ludzie w danej kulturze postrzegają wzrokowo, konceptualizują i wartościują otaczający ich świat. W terminologii fitoterapeutycznej ujawnia się wpływ szeroko rozumianej kultury, chociaż na pozór można go nie dostrzegać, np.: czarnuszka siewna / Schwarzkümmel - kulinaria: przyprawa, wypieki; czarny korzeń / Schwarzwurzel - lek na jad żmii, w wierzeniach ludowych ochrona domu przed nieszczęściami; bławatek/Kornblumenblau - chwast polny, kwiat cięty, składnik sałatek, barwnik, symbol pruskiej skromności, leksyka gwarowa; podkolan biały / weiße Waldhyazinthe - kwiat miłości²

Ze względu na rozległość materiałów źródłowych podstawową bazą analizy są słowniki, z których zaczerpnięta została zdecydowana większość przykładów: słowniki dwujęzyczne, w tym słownik specjalistyczny: Podręczny słownik niemiecko-polski (Psn-p), Podręczny słownik polsko-niemiecki (Psp-n), Podręczny słownik medyczny. Polsko-niemiecki i niemiecko-polski (Psm), Langenscheidts Taschenwörterbuch der polnischen und deutschen Sprache (LT), słowniki języka niemieckiego: Duden. Die deutsche Rechtschreibung (DddR), Duden. Deutsches Universalwörterbuch (DDU) oraz poradnik Rośliny lecznicze (Rl), z którego także pochodzą przedstawione $\mathrm{w}$ tabelach opisy właściwości analizowanych roślin³

W przeprowadzonym badaniu opisy roślin leczniczych zostały uporządkowane w sześciu zbiorach od barwy od najjaśniejszej do najciemniejszej: biały/weiß, żółty/gelb, czerwony/rot, zielony/grün, niebieski/blau, czarny/schwarz ${ }^{4}$. Analiza przebiega według następującego schematu: Najpierw omawiana jest grupa roślin, które zawierają ten sam element kolorystyczny

\footnotetext{
${ }^{2}$ Niniejsza analiza nawiązuje do mojej wcześniejszej pracy pt. Kolorowy świat w odbiorze Polaków i Niemców w szerszym kontekście językowo-kulturowym (Bawej 2018), w której ogólnie przedstawiono problematykę barw w świecie flory.

${ }^{3}$ Baza materiałowa obejmuje również własne przykłady nazw roślin leczniczych zbierane w latach 2015-2018. Przy przykładach wyekscerpowanych ze słowników podano ekwiwalent za autorem/autorami leksykonu oraz skrót źródła. Brak takiego skrótu przy danej jednostce oznacza, że pochodzi ona z materiałów własnych. W takich przypadkach podano własne tłumaczenie polskich nazw roślin na język niemiecki lub tłumaczenie według niemieckich wyszukiwarek (deutsche Suchmaschinen). W drugim przypadku przy danej jednostce widnieje skrót: $d S M$.

${ }^{4}$ Wybrane kolory spełniają lingwistyczne kryteria dla podstawowych nazw barw, sformułowane w pracy Brenta Berlina i Paula Kaya (1969: 5-7).
} 
w obu językach, np. gorczyca biata - weißer Senft, a potem zbiór roślin, które różnią się w nomenklaturze z uwagi na inny element kolorystyczny lub jego brak w jednym z języków, np. żywokost lekarski - Schwarzwurz. W wybranych przypadkach podano dosłowne tłumaczenie na język polski niemieckiego ekwiwalentu, żeby objaśnić podstawę motywacji w tworzeniu niemieckich nazw roślin leczniczych.

\section{Ziołolecznictwo - krótki rys historyczny}

Ludzie pierwotni dochodzili do informacji o ziołach na własna rękę, natomiast na podstawie dotychczas odkrytych zabytków kultury materialnej można stwierdzić, że pierwsze informacje o substancjach leczniczych i sporządzanych z nich miksturach pochodzą z egipskich papirusów, ksiąg chińskich i indyjskich ${ }^{5}$. W starożytnym Egipcie wykorzystywano substancje roślinne do sporządzania proszków, pigułek, czopków, maści, papek czy przecierów. Używano wszystkich części roślin: kwiatów, liści, owoców, korzeni i soku. W medycynie babilońskiej stosowane do leczenia substancje były przede wszystkim pochodzenia roślinnego. W starożytnej Grecji medycyna stała na wysokim poziomie, a zbieraniem i krajaniem ziół zajmowali się specjaliści nazywani „krajaczami korzeni”. W dawnych Indiach wierzono, że można sobie podporządkować tajemnice roślin leczniczych za pomocą magicznych zaklęć. Takie zaklęcia przechowały się w najstarszych świętych księgach. Głównym celem medycyny starożytnych Indii było przedłużanie życia ludzkiego, a jedną z najważniejszych dziedzin wiedzy medycznej stanowiła znajomość produktów leczniczych. Leki były głównie pochodzenia roślinnego, a uprawę roślin leczniczych organizowano i kontrolowano zgodnie z dekretami królów buddyjskich. W Chinach, obok akupunktury, najważniejszą dziedziną starej medycyny była farmakologia. Chińczycy wierzyli, że przyroda, a zwłaszcza rośliny, kryje w sobie lekarstwo na każdą chorobę. Lekarze starożytni sami przygotowywali swoje leki, używając materiałów dostarczanych im przez zielarzy i kupców. Niektórzy medycy byli szarlatanami, ponieważ przyrządzali z ziół najrozmaitsze płyny magiczne, napoje miłosne i trujące. Inni zaś rzetelnie interesowali się roślinami leczniczymi, zostawiając po sobie szkice i opisy roślin oraz wskazówki dotyczące ich działania. Na przykład Hipokrates, zwany ojcem medycyny, w swoich pismach opisuje wiele roślin leczniczych i ich oddziaływanie. W epoce Hipokratesa pojawiła się nawet teoria, że to sama przyroda wskazuje na właściwości lecznicze roślin, np. żółte kłącza

\footnotetext{
${ }^{5}$ Sekcja opracowana na podstawie prac: Bogunia, Kłoszewska [rok nieznany: 3] oraz Volák, Stodola (1987: 7-12).
} 
rzewienia (rabarbaru) stosowano przeciw żółtaczce. Pliniusz Starszy pisał, że zarówno ludy pierwotne, jak i lekarze greccy stosowanie ziół opierali na tradycji przekazywanej z pokolenia na pokolenie oraz objawów spożycia danej rośliny u ludzi i zwierząt. W ten sposób podobno odkryto środek na rozwolnienie, którego objawy występowały u kóz skubiących ciemiężycę biała. We wczesnym średniowieczu rozwinęła się tzw. medycyna klasztorna, znana z wypisów o leczniczych zaletach roślin. W Niemczech XII wieku ziołolecznictwo stało się popularne dzięki działalności słynnej opatki klasztoru pod Bingen, św. Hildegardy, której traktaty o ziołach wywarły duży wpływ na rozwój niemieckiej nomenklatury roślin leczniczych. Do rozszerzania zakresu wiedzy botanicznej przyczyniły się dwa wydarzenia: wynalezienie druku przez Gutenberga i odkrycie Ameryki przez Krzysztofa Kolumba. Ich bezpośrednim skutkiem było pojawienie się dużej liczny drukowanych zielników (herbaria) oraz sprowadzenie do Europy wielu nowych roślin leczniczych.

\section{Barwa i językowy obraz świata (JOS)}

W literaturze przedmiotu przyjmuje się, że barwa jest zjawiskiem fizycznym, fizykochemicznym oraz fizjologiczno-psychologicznym ${ }^{6}$. Kolor określa wszystko to, co jest widzialne. Jako obdarzone nim ludzie odbierają elementy otaczającego świata, które potrafią dostrzec, chociaż w różnym stopniu zwraca to ich uwagę, powodując wybrane zachowania słowne ujmujące barwę lub nie w opisie elementów rzeczywistości. W życiu codziennym ludzie nie koncentrują się na kolorze buraka czy kartofla jako oczywistym i jednakowym dla wszystkich przedstawicieli gatunku, chętnie jednak dyskutują o najsubtelniejszych odcieniach ubrań czy używanych przez nich przedmiotów. Percepcja barw nie zawsze jest więc świadoma, a na obudzenie tej świadomości mają wpływ potrzeby życiowe ludzi (Badyda 2008: 24-25).

We wszystkich kulturach ludzie ,widzą” i opisują to, co widzą, ale nie zawsze wydzielają „kolor” jako odrębny aspekt swojego doświadczenia wizualnego. Percepcja barw jest uniwersalna, ale ich rozróżnianie jest już uwarunkowane kulturowo. Dlatego konceptualizacja barw może być podobna lub różna w poszczególnych kulturach, istnieją również różnice indywidualne $\mathrm{w}$ procesie doświadczania i wartościowania świata, czyli odbierania wrażeń zmysłowych. To, co pojawia się w siatkówce i w mózgu, nie odbija się bezpośrednio w języku. Język odbija bowiem to, co się dzieje w umyśle, a nie to, co dzieje się w mózgu, ponieważ umysł

\footnotetext{
${ }^{6}$ Barwa postrzegana jest jako kategoria fizyczna (fala świetlna o określonej długości), kategoria biologiczna i neurofizjologiczna (relacje między wrażeniami kolorystycznymi a okiem i mózgiem) oraz kategoria psychologiczna (zdolność kojarzenia barw, psychologia użytkowa, chromoterapia) (Tokarski 2004: 21).
} 
ludzki jest do pewnego stopnia kształtowany przez konkretną kulturę (Wierzbicka 1999: 405411; 2006: 368-370). Nazwy barw są głęboko zakorzenione w codziennym życiu danej społeczności, przez co stają się nośnikami bogatej językowo sieci znaczeń w wybranej kulturze.

Główne założenia JOS, iż poszczególne języki różnią się od siebie odmiennymi oglądami otaczającej rzeczywistości, sformułował Wilhelm von Humboldt: (Humboldt 1908/1968: 17, cyt w: Anusiewicz, Dąbrowska, Fleischer 2000: 25).

Poprzez wzajemną zależność myśli i słowa jasne jest to, że języki nie są właściwie środkami przedstawiającymi już poznane prawdy, lecz są czymś daleko więcej, a mianowicie - środkami do odkrywania prawd dotychczas nie poznanych. Ich różnorodność nie jest li tylko różnorodnością dźwięków i znaków, lecz właściwie różnorodnością samych sposobów oglądu świata.

Leo Weisgerber uważał, że każda wspólnota językowa ma swój obraz świata zawarty w języku ojczystym. W każdym języku mieści się ustalony i określony porządek oraz ocena otaczającej rzeczywistości. JOS jest siłą działającą w języku, która przekształca świat materialny w świat duchowy przy współudziale danej wspólnoty językowej (Weisgerber 1953: $11-22)$.

Język jest podstawowym narzędziem poznawczym człowieka. Nazywanie tego, co otacza ludzi, związane jest z procesem poznawania rzeczy i zjawisk rzeczywistości pozajęzykowej. W języku utrwalone są wszystkie osiągnięcia wybranej wspólnoty, takie jak np.: zdobywane latami doświadczenia, własna tradycja, system wartości, wiara itp. Zdobycze i wartości kulturowe zawarte są w słowach, w ich znaczeniach, połączeniach wyrazowych. Cały system pojęciowy, który funkcjonuje w danym języku, jest produktem zbiorowej świadomości owej wspólnoty językowej (Łuczyński, Maćkiewicz 2002: 131-135).

Jerzy Bartmiński (2004: 104) podkreśla, że JOS jest zawartą w każdym języku interpretacją rzeczywistości, którą należy rozumieć jako pewien zespół sądów o otaczającym świecie i jego elementach. Oceny te są zachowane w języku, np.: w kategoriach gramatycznych, regułach derywacji, w słownictwie, znaczeniach słów, kolokacjach, przysłowiach czy wzorcach budowy zdań.

Język jest nie tylko narzędziem komunikowania się ludzi między sobą, ale także narzędziem myślenia danego narodu o rzeczywistości pozajęzykowej i jej elementach. Johann Gottfried Herder twierdził, że w języku zawarty jest duchowy świat w całym swym działaniu i przestrzeni. Ponieważ myślenie i odczuwanie zależą od języka, więc od języka zależy również 
odbiór świata (Herder 1951: 231; cyt. za: Mańczyk 1982: 34). Jak podaje Anna Krawczyk (1982: 29):

Rzeczywistość otaczająca człowieka nie jest sama przez się uporządkowana, podzielona na elementy. Nie tworzy w sposób naturalny żadnych klas. Dopiero człowiek, żyjąc w świecie, obserwując otoczenie i działając w nim - wyodrębnia pewne przedmioty, cechy, zjawiska. Ponieważ świat jest w swej złożoności przebogaty, nie jest możliwe zauważenie wszystkich jego aspektów. Dlatego dzieje się tak, że niektóre zjawiska i rzeczy są przez człowieka percypowane, a inne - pomijane. [...] Język jest ściśle powiązany z postrzeganiem i myśleniem. Człowiek, wyróżniając spośród morza zjawisk i przedmiotów jakieś jedno (jeden) - ma tendencje do nazywania go. I tak kształtuje się struktura słownictwa każdego języka. Stanowi ono odbicie nie tyle rzeczywistości, co sposobu, w jaki ta rzeczywistość jest postrzegana.

(Krawczyk (1982: 29)

JOS jest strukturą pojęciową, charakterystyczną dla każdego języka, za pomocą której ludzie mówiący tym językiem ujmują ( $\mathrm{tj}$. porządkują, nazywają i interpretują) świat. Struktura ta jest pochodną sposobu konceptualizacji świata obowiązującego w danej kulturze. Dlatego też analiza języka jest źródłem wiedzy o sposobie myślenia człowieka o świecie i o danym wycinku rzeczywistości pozajęzykowej (Kadrič, Kaindl, Kaiser-Cookie 2010: 29). Warto w tym kontekście przywołać także słowa Ryszarda Tokarskiego (2013: 35), który pisze:

Za każdym słowem czy połączeniem słów kryje się mniej lub bardziej utrwalona struktura pojęciowa, która pokazuje, w jaki sposób użytkownicy języka postrzegają i rozumieją określony obiekt świata zewnętrznego, zachodzące w nim procesy, dokonujące się działania itp. Każde wyrażenie językowe tworzy sobie tylko właściwy semantyczny 'mikroświat', w którym odbijają się ludzkie pragnienia, sposoby porządkowania i oceny rzeczywistości. (Tokarski 2013: 35),

Badania porównawcze semantyki leksykalnej pozwalają odkryć podobieństwa i różnice w sposobach konceptualizowania świata utrwalonych w różnych językach, tj. w językowym obrazie świata (Grzegorczykowa, Waszakowa 2000: 7). 


\section{Nazwy roślin leczniczych $\mathrm{z}$ elementem kolorystycznym}

\subsection{Bialy - weiß}

\begin{tabular}{|c|c|c|}
\hline Język polski & Język niemiecki & Opis rośliny \\
\hline ciemiężyca biała $(\mathrm{Rl})$ & weiße Nieswurz (dSm) & $\begin{array}{l}\text { bylina o białych kwiatach, } \\
\text { stosowana jako środek obniżający } \\
\text { ciśnienie krwi, przeciw skurczom } \\
\text { serca, atakom astmy i kokluszowi, } \\
\text { działa też napotnie } \\
\text { przeciwgorączkowo, wchodzi w } \\
\text { skład maści używanych do masaży } \\
\text { przeciwnewralgicznych } \\
\text { przeciwgośćcowych. Cała roślina } \\
\text { jest silnie trująca. }\end{array}$ \\
\hline gorczyca biała $(\mathrm{Rl})$ & weißer Senf & $\begin{array}{l}\text { roślina jednoroczna, której } \\
\text { owocem jest łuszczyna, } \\
\text { zawierająca jasne, białawe nasiona, } \\
\text { używana do sporządzania plastrów } \\
\text { przykładanych do bolesnych miejsc } \\
\text { przy schorzeniach gośćcowych }\end{array}$ \\
\hline grzybień biały $(\mathrm{Rl})$ & weiße Seerose (dSm) & $\begin{array}{l}\text { bylina wodna o białych kwiatach na } \\
\text { długich szypułkach, działa } \\
\text { cytostatycznie } \\
\text { (przeciwnowotworowo), wchodzi } \\
\text { w skład środków uśmierzających } \\
\text { popęd płciowy, tamuje krwawienia }\end{array}$ \\
\hline jasnota biała $(\mathrm{Rl})$ & weiße Taubnessel (dSm) & $\begin{array}{l}\text { bylina mająca u nasady górnych } \\
\text { liści białe kwiaty, działa } \\
\text { przeciwzapalnie, moczopędnie i } \\
\text { wykrztuśnie, tamuje krwawienia z } \\
\text { narządów rodnych i pobudza } \\
\text { procesy przemiany materii, leczy } \\
\text { nieżyt górnych dróg oddechowych, } \\
\text { zwalcza bezsenność, leczy egzemę, } \\
\text { oparzenia, żylaki odbytu i nóg }\end{array}$ \\
\hline koniczyna biała (Psp-n) & Weißklee & $\begin{array}{l}\text { roślina, której białe kwiaty są } \\
\text { zebrane w główki na długich } \\
\text { szypułkach, stosowana przeciw } \\
\text { nieżytom żołądkowo-jelitowym i } \\
\text { biegunkom, do leczenia chorób } \\
\text { górnych dróg oddechowych, } \\
\text { zapalenia gruczołów i bóli } \\
\text { gośćcowych }\end{array}$ \\
\hline podkolan biaty & weiße Waldhyazinthe (dSm) & $\begin{array}{l}\text { dawniej leczono nim bóle zębów, } \\
\text { bóle kobiece, stany zapalne, }\end{array}$ \\
\hline
\end{tabular}




\begin{tabular}{|l|l|l|}
\hline & weiße Johannisbeere (DDU) & $\begin{array}{l}\text { rozległe rany, wrzody, biegunkę, } \\
\text { zapalenia dróg moczowych }\end{array}$ \\
\hline porzeczka biała & $\begin{array}{l}\text { poprawia krążenie krwi, oczyszcza } \\
\text { organizm z toksyn, wykazuje } \\
\text { działanie przeciwzapalne, jest } \\
\text { źódłem magnezu, witaminy C i PP }\end{array}$ \\
\hline przestęp biały $(\mathrm{Rl})$ & weiße Zaunrübe (dSm) & $\begin{array}{l}\text { trująca bylina, która ma kwiaty w } \\
\text { kształcie korony o jasnożółtej lub } \\
\text { białej barwie, działa } \\
\text { przeczyszczająco, moczopędnie i } \\
\text { wymiotnie, stosowana w } \\
\text { przypadku gośćca i dny oraz w celu } \\
\text { usunięcia z organizmu szkodliwych } \\
\text { produktów przemiany materii }\end{array}$ \\
\hline
\end{tabular}

Biały i weiß w przytoczonych nazwach gatunkowych roślin leczniczych odnoszą się do ich wyglądu: białej, białawej lub jasnożółtej barwy ich części, tu kwiatów i owoców, np.: koniczyna biala - Weißklee, ciemiężyca biala - weiße Nieswurz, jasnota biala - weiße Taubnessel, przestęp bialy - weiße Zaunrübe. Barwa biała nawiązuje także do stopnia jasności ich nasion oraz owoców, np. gorczyca biata - weißer Senf, porzeczka biala - weiße Johannisbeere. Nasiona gorczycy i owoce tego gatunku porzeczki nie są białe, ale jako takie odbierają je zarówno Polacy, jak i Niemcy ${ }^{7}$. W tej grupie leksem biały w odniesieniu do wyglądu roślin może mieć znaczenie neutralne. Jeśli weźmiemy pod uwagę funkcję tych roślin, to biały nacechowany jest pozytywnie: uzdrawiający, mający właściwości lecznicze, oczyszczający organizm, zdrowy.

Biel jest też $\mathrm{w}$ obu kulturach symbolem doskonałości i podkreśla piękno rośliny, np. grzybień bialy - weiße Seerose - zwyczajowo nazywany nenufarem lub lilią wodą - ma efektowne, duże kwiaty pływające na powierzchni wody. Należy także dodać, że biel ma również negatywne znaczenie, ponieważ rośliny o białych kwiatach są często trujące, np. ciemiężyca biala - weiße Nieswurz, której kłącze zawiera trujące alkaloidy, dlatego kolory biaty i weiß mogą także konotować śmierć ${ }^{8}$.

7 Polski przymiotnik biały pierwotnie znaczył 'jasny, błyszczący, lśniący, blady’, wywodzi się on od prasłowiańskiego *bĕlb (Boryś 2005: 26). Niemiecki przymiotnik weiß pochodzi od indogermańskiego pnia *kuei, *kweit- 'świecić, błyszczeć, świecący, światło, jasny, biały', z którego wywodzi się starogermański przymiotnik wîz - 'jasny, świecący, lśniący' (Duden. Das Herkunftswörterbuch [2001: 921], por. także Kluge, Seebold [2002: 381]).

${ }^{8}$ Kolor biały jest m.in. symbolem życia wiecznego, świętości, chwały, mądrości, niewinności, czystości, małżeństwa, tchórzostwa, ale także śmierci i żałoby (Kopaliński 2015: 17). Na przykład w krajach słowiańskich i we Francji biały był kolorem żalu po śmierci kogoś bliskiego. Dlatego w dawnej Francji królewskie wdowy ubierały do końca życia białe suknie, a wdowy i dziewczęta z wyższych sfer aż do XVI wieku nosiły białe welony 
Dawniej Słowianie byli przekonani, że światło i jego blask były przyczyną wielu chorób. Na przykład w Polsce wierzono kiedyś, że jednym z powodów bólów u dzieci jest Księżyc jego światło i poświata, czyli przebywanie w świetlistej bieli. Słowianie uważali także, że zioła o białych kwiatach leczą bladość, czyli anemię. W tym kontekście warto dodać, że zioło o nazwie podkolan bialy (roślina o białych kwiatach i jasnych zgrubiałych częściach łodygi podziemnej) było uznawane za kwiat miłości. W jego podziemnych pędach Słowianie dopatrywali się symboli związku małżeńskiego, ponieważ przypominają one dwa złączone ze sobą serca (por. np. Komorowska 2010: 74, 81). Ludzie byli również przekonani o tym, że jeśli mężczyzna będzie jadł dużo podkolanu białego, to będzie miał syna. Jeśli kobieta będzie jadła podkolan, to urodzi córkę. W medycynie ludowej podkolan biaty uchodził za środek wzmacniający organizm i afrodyzjak. Wierzono również, że ma on właściwości ochronne i zabezpiecza ludzi od czarów (Chodurska 2003). Jego niemiecki ekwiwalent brzmi weiße Waldhyazinthe ('biały hiacynt leśny'), ponieważ w warunkach naturalnych rośnie on w widnych lasach liściastych, w zaroślach i na leśnych łąkach.

\subsection{Bialy $-\varnothing, \varnothing-w e i \beta$}

\begin{tabular}{|c|c|c|}
\hline Język polski & $\begin{array}{l}\text { Język niemiecki / } \\
\text { Dosłowne tlumaczenie }\end{array}$ & Opis rośliny \\
\hline białodrzew (LT) & $\begin{array}{l}\text { Silberpappel /'topola } \\
\text { srebrna' }\end{array}$ & $\begin{array}{l}\text { gatunek drzewa nazywanego także } \\
\text { topolą białą o białej korze, działa } \\
\text { dezynfekująco, moczopędnie, jest } \\
\text { skuteczny przeciwko nieżytom } \\
\text { górnych dróg oddechowych, } \\
\text { obniża zawartość mocznika we } \\
\text { krwi, uśmierza bóle stawów }\end{array}$ \\
\hline ciemiernik biały $(\mathrm{Rl})$ & $\begin{array}{l}\text { Schneerose }(\mathrm{dSm}) \text { / 'śnieżna } \\
\text { róża' }\end{array}$ & $\begin{array}{l}\text { bylina z białym kwiatem } \\
\text { wyglądem przypominającym } \\
\text { kwiaty dzikiej róży, stosowana do } \\
\text { leczenia chorób nerwowych, } \\
\text { działa silnie moczopędnie i } \\
\text { przeczyszczająco. W medycynie } \\
\text { weterynaryjnej stosowana do } \\
\text { leczenia zaburzeń w trawieniu i } \\
\text { przeciw owadom pasożytniczym }\end{array}$ \\
\hline glóg pospolity & $\begin{array}{l}\text { Weißdorn (Psn-p) / 'biały } \\
\text { cierń' }\end{array}$ & $\begin{array}{l}\text { ciernisty krzew o białych } \\
\text { kwiatach, stosowany do obniżenia } \\
\text { ciśnienia tętniczego krwi i przeciw } \\
\text { arteriosklerozie, działa usypiająco }\end{array}$ \\
\hline
\end{tabular}

żałobników. Białe chusty żałobników zakładali także Germanie i Słowianie. Istniały również pochówki z białym całunem, które w późniejszych latach stały się czarnymi pochówkami (Gross 1990: 85-109). 


\begin{tabular}{|c|c|l|}
\hline & & $\begin{array}{l}\text { na układ nerwowy, zawiera } \\
\text { witaminę C }\end{array}$ \\
\hline wierzba biała & $\begin{array}{c}\text { Silberweide (Psn-p) / } \\
\text { 'wierzba srebrna' }\end{array}$ & $\begin{array}{l}\text { roślina, której liście na spodzie są } \\
\text { białe lub srebrne, stosowana jako } \\
\text { środek przeciwzapalny, } \\
\text { przeciwgoraczkowy, } \\
\text { przeciwnewralgiczny, } \\
\text { przeciwgośćcowy, działa napotnie } \\
\text { podczas przeziębienia }\end{array}$ \\
\hline
\end{tabular}

Wybrane nazwy gatunkowe roślin leczniczych motywowane są w języku polskim białą lub jasną barwą ich części, tj. korą i liśćmi, np.: bialodrzew, wierzba biala. Leksem biaty ukazuje pozytywne właściwości rośliny. Natomiast język niemiecki nawiązuje do koloru srebra, np. Silberpappel, Silberweide, który jest tu synonimem dobrego, leczącego. Srebrny kolor ogniskuje w sobie cechę jasności i połysku. Srebro jako nazwa metalu wnosi do kolorystycznego określenia srebrny swoisty odcień metalicznego połysku (por. Tokarski 2004: 70-71), który jest widoczny na korze i liściach drzew zwłaszcza w słoneczne dni. Język niemiecki odwołuje się również do wzorca śniegu, np. Schneerose, czego nie ma w polskim językowym obrazie kwiatu - ciemiernik bialy ${ }^{9}$.

Z zestawienia wynika także, że gdy w języku niemieckim nazwa gatunkowa rośliny zawiera komponent bieli: Weißdorn - z uwagi na ostre ciernie bardzo jasne w świetle, jej polski ekwiwalent odnosi się do powszechnego występowania rośliny - głóg pospolity, która jest bardzo odporna, rośnie nawet na jałowych glebach i może tworzyć zarośla na miedzach, zboczach, polanach i skrajach lasów.

\section{3. Żólty - gelb}

\begin{tabular}{|l|l|l|}
\hline Język polski & Język niemiecki & \multicolumn{1}{|c|}{ Opis rośliny } \\
\hline goryczka żółta $(\mathrm{Rl})$ & gelber Enzian $(\mathrm{dSm})$ & $\begin{array}{l}\text { bylina o szerokoeliptycznych } \\
\text { liściach, które zakończone są } \\
\text { dużymi żółtymi kwiatami, pobudza } \\
\text { czynności wątroby, pęcherzyka } \\
\text { żółciowego i wydzielanie soku } \\
\text { żołądkowego, stosowana jako } \\
\text { środek wzmacniający }\end{array}$ \\
\hline grążel żółty $(\mathrm{Rl})$ & gelbe Teichrose $(\mathrm{SfwI})$ & $\begin{array}{l}\text { bylina wodna o dużych, źółtych } \\
\text { kwiatach, działa na organizm }\end{array}$ \\
\hline
\end{tabular}

\footnotetext{
${ }^{9}$ Podstawowymi odniesieniami dla bieli w językach europejskich są dzień i śnieg (aspekt kwantytatywny - dzień, aspekt kwalitatywny - śnieg), por. np.: Waszakowa (2000: 23); Tokarski (2004: 40, 75); Stanulewicz (2006: 202); Wierzbicka (2006: 341).
} 


\begin{tabular}{|c|c|c|}
\hline & & $\begin{array}{l}\text { pobudzająco, wchodzi w skład } \\
\text { leków, które wpływają na } \\
\text { ośrodkowy układ nerwowy }\end{array}$ \\
\hline naparstnica żólta (Psm) & gelber Fingerhut & $\begin{array}{l}\text { wieloletnia roślina } \\
\text { dzwonkowatych cytrynowożółtych } \\
\text { kwiatach, stosowana } \\
\text { przypadkach ostrej niewydolności } \\
\text { mięśnia sercowego, tachykardii i } \\
\text { nieregularnej pracy serca }\end{array}$ \\
\hline
\end{tabular}

Leksemy żółty/gelb w nazwach przytoczonych roślin nawiązują w obydwu językach do koloru kwiatów ziół. Żólty jest określeniem pozytywnym, odnosi się do wyglądu dojrzałych roślin, kwitnących latem, pomagających nie tylko leczyć różne dolegliwości, ale także przyjemnych dla ludzkiego oka, chętnie uprawianych jako rośliny ozdobne, np. naparstnica żótta - gelber Fingerhut, grążel żólty - gelbe Teichrose. Żółte kwiaty są podobne do koloru słońca, które tutaj jest prototypem barwy ${ }^{10}$. Goryczka zólta - gelber Enzian ma nie tylko żółte kwiaty, czym motywowana jest nazwa w obydwu językach, ale także gorzki smak, co dodatkowo odzwierciedla nazwa polska. Warto dopowiedzieć, że roślinami w żółtym kolorze leczono i leczy się choroby układu trawiennego, wywołane nadmiernym wydzielaniem żółci, np.: naparem z dziurawca, nawłoci czy mniszka lekarskiego.

Żólty jest tutaj związany ze światłem słonecznym, zawiera w swojej warstwie znaczeniowej pozytywne wartości, ponieważ konotuje on przyjazną przyrodę: śliczne kwiaty i zdrowe zioła. Nazwy roślin łączą się ze słońce, gorącym latem, czasem wakacji, ale także intensywnej pracy w polu czy w ogrodzie. Żółty i gelb w tej grupie są synonimem miłego uczucia i rzeczy przyjemnej, chociaż zasadniczo żółty jest symbolem obłudy, zdrady małżeńskiej, zazdrości, fałszu, kłamstwa, choroby i melancholii (por. np. Kopaliński 2015: 512) ${ }^{11}$.

W badanym materiale nie znaleziono przykładów roślin leczniczych, które łączyłyby się z przymiotnikami żółty lub gelb w jednym języku a w drugim nie. Świadczy to o tym, iż Polacy i Niemcy tak samo postrzegają zioła o żółtych kwiatach.

10 Por. np.: Wierzbicka (1999: 431, 433, 2006: 352, 353); Waszakowa (2000: 23); Tokarski (2004: 107); Stanulewicz (2006: 202).

${ }^{11}$ Johann Wolfgang von Goethe (1981: 296-297) wyttumaczył to w swoim dziele pt. Farbenlehre w następujący sposób: żółty kolor w czystym stanie wnosi jasność, ma pogodny, żywy charakter, rozwesela duszę, sprawia wrażenie ciepła i przytulności. Jeżeli barwa ta w swej czystej i jasnej postaci zostanie zabrudzona, zmieszana, pokryje nieczyste lub nieszlachetne powierzchnie, np. zwykłe sukno czy filc, zaczyna sprawiać nieprzyjemne wrażenie. W ten sposób kolor godności i chwały zamienia się w barwę hańby, wstrętu i niesmaku. 


\subsection{Czerwony - rot}

\begin{tabular}{|l|l|l|}
\hline Język polski & Język niemiecki & \multicolumn{1}{|c|}{ Opis rośliny } \\
\hline$d a ̨ b$ czerwony & Roteiche $($ Psn-p) & $\begin{array}{l}\text { stosowany w przypadku biegunek i } \\
\text { zapalenia węzłów chłonnych, do } \\
\text { gojenia trudno zabliźniających się } \\
\text { ran, do hamowania krwawień z } \\
\text { nosa i ran, do płukania gardła }\end{array}$ \\
\hline
\end{tabular}

W analizowanych źródłach odnotowano tylko jedną nazwę rośliny leczniczej z czerwonym elementem, którą tak samo „widzą” Polacy i Niemcy. Czerwoną barwą motywowana jest w obydwu językach nazwa efektownego dębu czerwonego - Roteiche, drzewa, którego liście jesienią robią się czerwone (są w kolorze zbliżonym do koloru krwi albo barwy palącego się ognia $)^{12}$. Kolor czerwony ma pozytywny wydźwięk, ponieważ kojarzy się z pogodną jesienią porą ciepłą, słoneczną, suchą i bardzo kolorową. Jesień w tym kontekście nie jest czasem, w którym zamiera życie, jest ponuro i pada deszcz, ale czasem, kiedy liście na drzewach mienią się różnymi kolorami, a niebo jest czyste. Jest to również pora, w czasie której Polacy bardzo chętnie zbierają grzyby, np. pod dębami rosą podgrzybki i borowiki szlachetne, co nie jest tak popularne wśród Niemców.

\subsection{Czerwony - o}

\begin{tabular}{|l|c|l|}
\hline Język polski & $\begin{array}{c}\text { Język niemiecki / } \\
\text { Dosłowne tlumaczenie }\end{array}$ & \multicolumn{1}{|c|}{ Opis rośliny } \\
\hline buławinka czerwona $(\mathrm{Rl})$ & $\begin{array}{c}\text { Mutterkornpilz (dSm) / } \\
\text { 'grzyb sporysz' }\end{array}$ & $\begin{array}{l}\text { grzyb porażający kłosy żyta, } \\
\text { powoduje skurcz mięśni gładkich } \\
\text { macicy, zmniejsza pobudliwość } \\
\text { nerwów współczulnych, powoduje } \\
\text { skurcz naczyń krwionośnych } \\
\text { obwodowego układu żylnego, } \\
\text { zwiększa ciśnienie tętnicze }\end{array}$ \\
\hline ciemiernik czerwony & $\begin{array}{c}\text { Nieswurz }(\mathrm{dSm}) \\
\text { 'ciemiernik' }\end{array}$ & $\begin{array}{l}\text { stosowany do leczenia niektórych } \\
\text { chorób nerwowych }\end{array}$ \\
\hline czerwona koniczyna & 'kiesenklee (dSm) / & $\begin{array}{l}\text { do leczenia nieżytu oskrzeli, } \\
\text { kaszlu, chrypki i biegunki, }\end{array}$ \\
\hline
\end{tabular}

\footnotetext{
12 Tokarski (2004: 31, 80; 2013: 236) uważa, że zgodnie z przyjętą od dawna tradycją i definicjami czerwieni znaczenie tej nazwy barwy modelowane jest przez 'krew' i 'ogień'. Podobnego zdania jest Wierzbicka (2006: 351-353), która przyjmuje takie same referencje prototypowe czerwieni.
} 


\begin{tabular}{|c|c|l|}
\hline & Mohne (dSm)/ 'maki' & $\begin{array}{l}\text { stosowana w okładach przeciwko } \\
\text { chorobom skórnym }\end{array}$ \\
\hline czerwone maki & $\begin{array}{l}\text { stosowane jako środek } \\
\text { uspokajający, przeciw chrypce i } \\
\text { suchemu kaszlowi }\end{array}$ \\
\hline miodunka czerwona & $\begin{array}{c}\text { Lungenkräuter }(\mathrm{dSm}) / \text { 'zioła } \\
\text { naca' }\end{array}$ & $\begin{array}{l}\text { działa wykrztuśnie, używana do } \\
\text { leczenia nieżytu oskrzeli, kaszlu } \\
\text { oraz kokluszu, działa napotnie, } \\
\text { przeciwzapalnie, ściągająco, } \\
\text { dezynfekująco i przeciwzapalnie }\end{array}$ \\
\hline
\end{tabular}

Jak wynika z powyższego, w przypadku czerwonego jest więcej różnic między Polakami a Niemcami przy postrzeganiu obiektów rzeczywistości pozajęzykowej, jakimi są rośliny lecznicze w czerwonym kolorze.

Czerwony ma wiele znaczeń, jest m.in. jest symbolem ciała ludzkiego, energii, krzepkości, rumieńca, zdrowia, znakiem krążenia soków żywotnych (Kopaliński 2015: 51). Potwierdzeniem takich pozytywnych właściwości czerwonego są przytoczone powyżej przykłady ziół w języku polskim, których ekwiwalenty w języku niemieckim nie mają elementu kolorystycznego w swojej nazwie. Użycie czerwieni $\mathrm{w}$ tym zestawieniu jest niewątpliwie związane $\mathrm{z}$ wyglądem roślin. Koniczyna czerwona ma wprawdzie ciemnoróżowe kwiaty, które Polacy odbierają jako czerwone, dla Niemców istotne jest jednak miejsce występowania rośliny: Wiesenklee 'koniczyna łąkowa'. W języku polskim w odniesieniu do maków utrwaliło się połączenie czerwone maki, które najczęściej rysuje się, maluje czy haftuje na obrusach i bluzkach w kolorze czerwonym ${ }^{13}$, natomiast niemieckie określenie rośliny nie posiada komponentu barwy. Czerwony łączy się nazwą grzyba buławinka czerwona, która motywowana jest czerwonym kolorem grzybni, natomiast w języku niemieckim nawiązuje się do kształtu ziarna, w postaci którego występuje ta choroba - Mutterkornpilz. Miodunka czerwona swoją nazwę zawdzięcza czerwonym kwiatom, zaś jej niemiecki ekwiwalent odnosi się do pozytywnych właściwości ziela i funkcji, jaką spełnia: Lungenkräuter 'zioła na płuca', wywar z rośliny stosuje się bowiem przy chorobach płuc. Także ciemiernik czerwony ma czerwone, a niekiedy nawet ciemnoczerwone lub fioletowe kwiaty, czego nie utrwalono w jego niemieckim ekwiwalencie - Nieswurz.

\footnotetext{
${ }^{13}$ Tylko maki ogrodowe, wyhodowane przez człowieka, mogą mieć inne barwy.
} 


\subsection{Niebieski-blau}

\begin{tabular}{|c|c|c|}
\hline Język polski & Język niemiecki & Opis rośliny \\
\hline blawatek (chaber) & Kornblumenblau & $\begin{array}{lr}\text { działa moczopędnie, } & \text { pobudza } \\
\text { przemianę materii, } & \text { reguluje } \\
\text { trawienie, leczy zaburzenia } \\
\text { żołądkowe, służy } \\
\text { przygotowywania } & \text { kąpieli } \\
\text { leczących rany, owrzodzenia oraz } \\
\text { jako składnik płynów do } \\
\text { pielęgnacji włosów }\end{array}$ \\
\hline
\end{tabular}

Nazwa blawatek i jego niemiecki ekwiwalent Kornblumenblau motywowane są niebieską barwą koloru płatków kwiatu. Bławatek jest nie tylko rośliną leczniczą, lecz także ozdobną stosowaną jako kwiat cięty. Dawniej z jego płatków wytwarzano niebieską farbę do barwienia tkanin. Jest to również roślina jadalna dodawana do sałatek. W tym kontekście warto dodać, że niebieski w języku polskim zachował się w starych nazwach bławy, bławatny, które należą do leksyki gwarowej. Jako określenia barwy niebieskiej zniknęły one ze współczesnego języka polskiego.

W Niemczech bławatek jest symbolem pruskiej skromności ${ }^{14}$, był on także ulubionym kwiatem Kaszubów i Wilhelma I Hohenzollerna ${ }^{15}$ (www.berliner-zeitung.de/berlin/preussischblau, DW 12.01.2019).

Niebieski i blau mają pozytywne skojarzenia, wiążące się łagodzeniem bólu, urodą, poczuciem piękna, harmonią, przyjemnością i prostotą.

\section{7. - blau}

\begin{tabular}{|c|c|c|}
\hline Język polski & $\begin{array}{l}\text { Język niemiecki / } \\
\text { Dosłowne tlumaczenie }\end{array}$ & Opis rośliny \\
\hline czarna jagoda & $\begin{array}{l}\text { Blaubeere (LT) / 'niebieska } \\
\text { jagoda' }\end{array}$ & $\begin{array}{l}\text { obniża poziom cukru we krwi, } \\
\text { leczy cukrzycę, nieżyty } \\
\text { żołądkowo-jelitowe, zapalenia } \\
\text { pęcherza, biegunkę, zapalenie jamy } \\
\text { ustnej i gardła }\end{array}$ \\
\hline tojad mocny & $\begin{array}{l}\text { blauer Eisenhut (DddR) / } \\
\text { 'niebieski tojad' }\end{array}$ & $\begin{array}{l}\text { jest składnikiem preparatów } \\
\text { przeciwbólowych stosowanych } \\
\text { przy gośćcu, dnie, rwie kulszowej, } \\
\text { bólach zębów, także w chorobach i }\end{array}$ \\
\hline
\end{tabular}

\footnotetext{
${ }^{14}$ Mieszkańcom Prus przypisywano tzw. cnoty pruskie (preußische Tugenden), które wyznaczał pruski system wartości, np.: uczciwość, szczerość, pilność, religijność itp.

${ }^{15}$ Wilhelm I Hohenzollern - król Prus od 1861, cesarz niemiecki od 1871 (Meyers Grosses Handlexikon 1989: 974).
} 


\begin{tabular}{|l|l|l|}
\hline & & $\begin{array}{l}\text { bólach spowodowanych } \\
\text { przeziębieniem }\end{array}$ \\
\hline
\end{tabular}

Obydwie nazwy roślin leczniczych postrzegane są przez Niemców jako niebieskie. Inaczej jest w języku polskim. Barwą motywowana jest tylko czarna jagoda. W tym miejscu należy zauważyć, że Polacy „widzą” jej czarne kulki, a Niemcy postrzegają je jako niebieskie Blaubeere ('niebieskie jagody'). Z etymologii przymiotnika blau wynika, że w języku niemieckim kolor ten był konceptualizowany jako ciemny, ciemnoniebieski (Duden. Das Herkunftswörterbuch 2001: 100).

Określenie drugiej rośliny leczniczej Polacy odnoszą do cech innych niż barwa. W nazwie tojada mocnego w języku niemieckim - blauer Eisenhut - odzwierciedlany jest kolor niebieskich kwiatów w kształcie hełmu, a w języku polskim podkreśla się działanie rośliny: tojad jest bardzo trującą rośliną działającą na układ nerwowy oraz składnikiem silnych leków przeciwbólowych, sprzedawanych tylko na receptę lekarską.

W obu analizowanych grupach nazw roślin z leksemami niebieski i blau można zauważyć, że $\mathrm{w}$ nazewnictwie $\mathrm{w}$ języku polskim zwraca się albo na kolor części rośliny, albo na jej właściwości. W języku niemieckim nazwy nadawane są ze względu na barwę owoców lub kwiatów. Niebieskiemu i blau można przypisać tu zarówno właściwości pozytywne: smaczny, zdrowy, chroniący, uspokajający, kojący, jak i ujemne: trujący, niebezpieczny, zły.

\subsection{Zielony - grün}

\begin{tabular}{|l|l|l|}
\hline Język polski & Język niemiecki & \multicolumn{1}{|c|}{ Opis rośliny } \\
\hline ciemiężyca zielona $($ Psm) & grüne Nieswurz & $\begin{array}{l}\text { środek obniżający ciśnienie krwi, } \\
\text { stosowana przeciwko atakom } \\
\text { astmy i kokluszowi, działa } \\
\text { napotnie i przeciwgorączkowo }\end{array}$ \\
\hline mięta zielona & grüne Minze & $\begin{array}{l}\text { pobudza apetyt, leczy dolegliwości } \\
\text { żołądkowe, wzdęcia, biegunki, } \\
\text { osłabia skurcze przewodu } \\
\text { pokarmowego, pobudza } \\
\text { wydzielanie żółci, stosowana w } \\
\text { inhalacjach przeciwko katarowi, } \\
\text { zapaleniu gardła, nieżytowo } \\
\text { działanie } \\
\text { oskrzeli, ma } \\
\text { antyseptyczne }\end{array}$ \\
\hline
\end{tabular}

Chociaż zielony jest atrybutem świata flory, w materiale egzemplifikacyjnym pochodzącym z badanych źródeł tylko dwie nazwy gatunkowe roślin leczniczych konceptualizowane są ich 
zielona barwą w obydwu językach, tu barwą liści: ciemiężyca zielona - grüne Nieswurz, mięta zielona - grüne Minze. Teodorowicz-Hellman (2000: 76) thumaczy to w ten sposób, że cecha zieloności wydaje się być w pewnym sensie wpisana już w samo pole znaczeniowe wielu roślin, dlatego dodawanie atrybutu zieloności jest informacją dodatkową i zbyteczną.

Zielony - grün zawiera pozytywną ocenę rzeczywistości: uzdrawiający, leczący, uspokajający, odświeżający, zdrowy.

\subsection{Zielony -}

\begin{tabular}{|c|c|c|}
\hline Język polski & $\begin{array}{l}\text { Język niemiecki / } \\
\text { Dosłowne tlumaczenie }\end{array}$ & Opis rośliny \\
\hline zielona koniczyna & $\begin{array}{c}\text { Wiesenklee } \\
\text { 'koniczyna łąkowa' }\end{array}$ & $\begin{array}{l}\text { leczy nieżyt oskrzeli, kaszel, } \\
\text { chrypkę, biegunkę, stosowana w } \\
\text { okładach przeciw chorobom } \\
\text { skórnym }\end{array}$ \\
\hline
\end{tabular}

Inaczej przedstawia się JOS w przypadku koniczyny, która w języku polskim występuje $\mathrm{z}$ leksemem zielony z uwagi na kolor liści o trzech lub czterech działkach. W języku niemieckim nazwa zioła motywowana jest miejscem jego występowania, czyli łąką - Wiesenklee.

Zielony oddaje nie tylko stronę wizualną rośliny, ale zawiera $\mathrm{w}$ swojej warstwie znaczeniowej same jej pozytywne właściwości: odkażający, łagodzący, uśmierzający.

\subsection{Czarny - schwarz}

\begin{tabular}{|c|c|c|}
\hline Język polski & Język niemiecki & Opis rośliny \\
\hline ciemiężyca czarna & schwarze Nieswurzel (Psm) & $\begin{array}{l}\text { obniża ciśnienie krwi, stosowana w } \\
\text { kardiologii, przeciw skurczom } \\
\text { serca, astmie i kokluszowi, działa } \\
\text { napotnie i przeciwgorączkowo, } \\
\text { używana do masaży } \\
\text { przeciwnewralgicznych } \\
\text { przeciwgośćcowych }\end{array}$ \\
\hline czarnuszka siewna & Schwarzkümmel (LT) & $\begin{array}{l}\text { działa żółciopędnie, moczopędnie, } \\
\text { wiatropędnie, } \\
\text { przeciwrobaczycowo oraz } \\
\text { rozkurczająco na mięsnie gładkie, } \\
\text { wzmaga wydzielanie mleka, } \\
\text { stosowana także w przypadku } \\
\text { nieżytu oskrzeli }\end{array}$ \\
\hline czarny bez (Rl) & schwarzer Holunder (dSm) & $\begin{array}{l}\text { działa napotnie, leczy nieżyty } \\
\text { górnych dróg oddechowych } \\
\text { słabych zaburzeń nerwowych, }\end{array}$ \\
\hline
\end{tabular}




\begin{tabular}{|c|c|c|}
\hline & & $\begin{array}{l}\text { zawiera witaminę } C \text {, ma działanie } \\
\text { słabo przeczyszczające, wchodzi w } \\
\text { skład mieszanek ziołowych } \\
\text { odchudzających, leczy bezsenność, } \\
\text { migrenę, bóle głowy i bolesne } \\
\text { stany zapalne }\end{array}$ \\
\hline gorczyca czarna $(\mathrm{Rl})$ & schwarzer Senf & $\begin{array}{l}\text { poprawia ukrwienie skóry i } \\
\text { narządów wewnętrznych (płuc, } \\
\text { opłucnej, nerek), leczy gośćca, } \\
\text { skurcze i zmęczenie mięśni }\end{array}$ \\
\hline lulek czarny (RL) & schwarzes Bilsenkraut (dSm) & $\begin{array}{l}\text { stosowany do produkcji leków } \\
\text { przeciwastmatycznych } \\
\text { rozkurczowych, lagodzących stany } \\
\text { pobudzenia nerwowego, uspokaja } \\
\text { drżenie starcze, leczy bóle } \\
\text { gośćcowe }\end{array}$ \\
\hline malwa czarna $(\mathrm{Rl})$ & schwarze Malve (dSm) & $\begin{array}{l}\text { używana w przypadku zapalenia } \\
\text { błony śluzowej gardła, przeciw } \\
\text { kaszlowi i astmie, przy leczeniu } \\
\text { chronicznego stanu zapalnego } \\
\text { żołądka i jelit oraz obstrukcji, leczy } \\
\text { choroby skóry }\end{array}$ \\
\hline mierznica czarna $(\mathrm{RL})$ & Schwarznessel (dSm) & $\begin{array}{l}\text { używana jako środek uspokajający } \\
\text { w przypadku chorób nerwowych: } \\
\text { depresji, migreny, neurastenii, } \\
\text { stanów niepokoju, działa też } \\
\text { napotnie }\end{array}$ \\
\hline topola czarna & Schwarzpappel (Psn-p) & $\begin{array}{l}\text { działa dezynfekująco i } \\
\text { moczopędnie, leczy nieżyty } \\
\text { górnych dróg oddechowych, } \\
\text { obniża zawartość mocznika we } \\
\text { krwi, łagodzi bóle stawów }\end{array}$ \\
\hline wężymord czarny korzeń & Schwarzwurzel (LT) & $\begin{array}{l}\text { zawiera potas, żelazo, fosfor, } \\
\text { witaminy E, B1, B2, C, obniża } \\
\text { poziom cukru we krwi, poziom } \\
\text { złego cholesterolu, poprawia } \\
\text { trawienie, oczyszcza organizm z } \\
\text { toksyn }\end{array}$ \\
\hline
\end{tabular}

Bogatą grupę nazw stanowią określenia roślin leczniczych z komponentami czarny i schwarz, w których barwa odnosi się do wyglądu zioła, np. przymiotniki czarny i schwarz opisują kolor wybranej części obiektu, przenosząc przy tym metonimicznie kolor owocu, nasion czy kwiatu na kolor całej rośliny. Leksemy czarny i schwarz nawiązują też do właściwości roślin. 
Ciemiężyca czarna - schwarze Nieswurzel jest ziołem o czerwonobrunatnych kwiatach, które z daleka wyglądają jak czarne. Czarny bez - schwarzer Holunder ma czarne, błyszczące jagody. Krzew ten sadzono w pobliżu chłopskich zagród, aby strzec domu i dobytku od złego, czarów, pożarów, zarazy i różnych chorób (Komorowska 2010: 73) ${ }^{16}$. Dawniej w Polsce i w Niemczech prętem z czarnego bzu mierzono nieboszczyka, aby dopasować mu trumnę. Pod bzem wylewano wodę po umyciu zmarłego, co miało uchronić członków jego rodziny od rychłej śmierci. Ponieważ wierzono, że z czarnym bzem związane są siły nieczyste, matki śmiertelnie chorych dzieci zanosiły je pod krzew, mając nadzieję, że dzieciom pomogą chociaż złe moce (Ziółkowska 1983: 18-25). Czarny bez w kulturze germańskiej kojarzony był z Holdą (mityczną germańską przewodniczką zmarłych), dlatego jego ścinanie było uważane za świętokradztwo (www.zycieaklimat.edu.pl/Bzy, DW: 24.01.2019). Czarnuszka siewna - Schwarzkümmel jest rośliną, której owocem jest mieszek, zawierający czarne pachnące nasiona, które służą jako dodatek do różnych potraw. Podobnie czarne nasiona ma gorczyca czarna - schwarzer Senf, które wykorzystywane są w celach leczniczych oraz do produkcji musztardy. Malwa czarna schwarze Malve ma ciemofioletowe kwiaty, które z daleka wyglądają jak czarne. Mierznica czarna - Schwarznessel jest rośliną, której listki i łodygi pokryte są włoskami dającymi ciemny odcień. Topola czarna - Schwarzpappel ma szaro-czarną korę, na starszych egzemplarzach nawet czarną. Wężymord czarny korzeń - Schwarzwurzel, jak wskazuje nazwa, ma czarną podziemną część rośliny. Polska nazwa wywodzi się z dawnych czasów, kiedy w medycynie ludowej używano tego warzywa jako leku na jad żmii. W języku niemieckim natomiast istotna jest brunatna lub czarna barwa korzenia, a nie jego właściwości lecznicze. Czarny korzeń miał też chronić dom przed pożarami i różnymi nieszczęściami.

W przypadku większości ziół czarny i schwarz służą do wyrażania dobrych właściwości: zdrowy, smaczny, odkażający, oczyszczający, łagodzący, uśmierzający ból, uspokajający. Ale stosowanie niektórych ziół było dawniej związane z czarami, magicznymi zabiegami, leczeniem „czarnych” (,złych”) chorób. W określeniach ziół, zwłaszcza tych o toksycznych właściwościach, znajdują odzwierciedlenie metaforyczne znaczenia: czarnego - zły, niebezpieczny, niepokojący, grzeszny, związany z szatanem, niosący śmierć (por. Chodurska 2010: 47). Zioła te leczyły choroby budzące strach wśród ludzi, np. choroby nerwowe kojarzące się z siłami nieczystymi i opętaniem, a ich przedawkowanie mogło doprowadzić do trwałego

\footnotetext{
${ }^{16}$ Kolor czarny łączy się najczęściej ze zjawiskami i cechami negatywnymi. Czarna barwa jest symbolem zła, niebezpieczeństwa, tragedii, zniszczenia, niemoralności, przesądów, zmartwienia, oszustwa, smutku, żałoby, bóstw podziemia, nocy, śmierci, potępienia, Piekła, diabła, czarnej magii i grzechu (Kopaliński 2015: 48).
} 
kalectwa lub śmierci, np. mierznica czarna - Schwarznessel stosowana w chorobach nerwowych i psychicznych czy lulek czarny - schwarzes Bilsenkraut mający brunatne, ciemne nasiona, zawierające trujące alkaloidy działające na ośrodkowy układ nerwowy. Jego spożycie wywołuje odurzenie, nienaturalne zachowanie, brak opanowania oraz senność, które dawniej kojarzono z opętaniem przez diabła i demony.

\subsection{Czarny -o, o-schwarz}

\begin{tabular}{|c|c|c|}
\hline Język polski & $\begin{array}{l}\text { Język niemiecki / } \\
\text { Dosłowne tlumaczenie }\end{array}$ & Opis rośliny \\
\hline $\begin{array}{c}\text { borówka czernica, czarna jagoda } \\
(\mathrm{Rl})\end{array}$ & $\begin{array}{c}\text { Heidelbeere, Blaubeere } \\
\text { /'jagoda z boru', 'niebieska jagoda' }\end{array}$ & $\begin{array}{l}\text { pomaga leczyć cukrzycę, leczy } \\
\text { nieżyty żołądkowo-jelitowe, } \\
\text { zapalenie pęcherza, biegunkę, } \\
\text { zapalenie jamy ustnej i gardła }\end{array}$ \\
\hline śliwa tarnina & $\begin{array}{l}\text { Schwarzdorn (DddR) / } \\
\text { 'czarny ciern'' }\end{array}$ & $\begin{array}{l}\text { stosowana przy schorzeniach } \\
\text { układu moczowego, jako lek } \\
\text { przeczyszczający, działa także } \\
\text { rozkurczowo na mięśnie gładkie } \\
\text { przewodu pokarmowego }\end{array}$ \\
\hline żywokost lekarski & $\begin{array}{l}\text { Schwarzwurz } \\
\text { 'czarny korzeń' }\end{array}$ & $\begin{array}{l}\text { działa przeciwzapalnie, uśmierza } \\
\text { bóle zębów, zapobiega } \\
\text { paradontozie, leczy bóle gośćcowe, } \\
\text { żylaki, wrzody, egzemy, choroby } \\
\text { chroniczne dróg oddechowych, } \\
\text { wrzody żołądka, gruźlice, } \\
\text { biegunki, łagodzi bóle stawów }\end{array}$ \\
\hline
\end{tabular}

W językowym obrazie czarnego i schwarz w odniesieniu do ziół są też różnice, które potwierdzają przytoczone przykłady. Czarna jagoda nazywana borówka czernica w języku polskim, w języku niemieckim określana jest jako 'jagoda z boru' (miejsce występowania), 'niebieska jagoda' (kolor), regionalnie także Schwarzbeere ('czarna jagoda'). W polskim językowym obrazie jagody mają czarny kolor, chociaż w rzeczywistości są ciemnoniebieskie, na co zwracają uwagę Niemcy. Czarne owoce z niebieskim nalotem ma także śliwa tarnina, nazywana po niemiecku Schwarzdorn ze względu na prawie czarny kolor kolców. W przypadku żywokosta lekarskiego niemiecki ekwiwalent rośliny motywowany jest barwą jej korzenia Schwarzwurz, natomiast nazwa polska konotuje właściwości lecznicze rośliny.

Warto tu dodać, że atrybuty czarny i schwarz w nazwach wielu roślin nie wskazują na typowo czarny kolor, lecz na ciemniejszy odcień barwy całego obiektu lub jego części, np.: fioletowy, ciemno-brudnoczerwony lub bardzo ciemne odcienie zieleni. 


\section{Podsumowanie}

Przedstawione zestawienie nazw gatunkowych roślin leczniczych z elementem kolorystycznym w języku polskim i niemieckim skłania do kilku refleksji. Przede wszystkim podkreśla ciągłą potrzebę stosowania ujęć kontrastywnych w zakresie sposobów sposoby nazywania obiektów rzeczywistości w poszczególnych kulturach, ponieważ na przykład percepcja barw jest uniwersalna, ale ich doświadczanie, konceptualizacja i wartościowanie są uwarunkowane kulturowo.

Analiza kolorów w nomenklaturze roślin leczniczych rzuca też pewne światło na problem kształtowania się JOS $\mathrm{w}$ odniesieniu do przedmiotowego wycinka rzeczywistości pozajęzykowej otaczającej Polaków i Niemców. Pokazuje ona, że obydwa języki mogą charakteryzować się w niektórych przypadkach podobieństwem JOS, w innych różnić się w opisywaniu otaczającej rzeczywistości, co wynika z utrwalonej w każdym języku określonej wiedzy o świecie, wybranej postawy wobec niego, sposobu myślenia o otaczającej rzeczywistości pozajęzykowej, zdobywanego doświadczenia, zarówno fizycznego, jak i kulturowego użytkowników obydwu języków. Elementy kolorystyczne w nazwach roślin obejmują i sferę wartości kulturowych i językowych zarówno ogólnie, jak i z punktu widzenia obydwu narodów i ich języków. Językowy obraz wybranych obiektów rzeczywistości pozajęzykowej, jakim są tu nazwy roślin leczniczych z komponentem barwy, zależy nie tylko od samego wyglądu rośliny, jej walorów smakowych, wartości, funkcji i mocy, ale również od danej zbiorowości, która patrzy na świat z określonego punktu widzenia, i która w zależności od swoich potrzeb i skojarzeń wyróżnia lub nie określone cechy, nazywając roślinę w swoim języku.

Ogląd nazw roślin „zawierających” kolory jest także źródłem ciekawych danych odnośnie dominacji kolorystycznych $\mathrm{w}$ obydwu językach $\mathrm{Z}$ badania wynika, że język polski jest nieznacznie bogatszy w opisywanym zakresie niż język niemiecki. W języku polskim nazwy kolorów zostały wykorzystane 33 razy do tworzenia nazw ziół, a w języku niemieckim wystąpiło 29 nazw roślin z elementem kolorystycznym. Największą reprezentację znalazły biel (język polski - 11 jednostek, język niemiecki - 9 jednostek) i czerń (język polski - 11 jednostek, język niemiecki 11 jednostek). Dlatego biały - jako kolor najjaśniejszy - i czarny - jako kolor najciemniejszy - są tutaj niejako klamrą spajającą obraz świata „kolorowych” roślin leczniczych. 


\section{Bibliografia}

Anusiewicz, Janusz, Anna Dąbrowska, Michael Fleischer (2000) „Językowy obraz świata i kultura. Projekt koncepcji badawczej”. [W:] Anna Dąbrowska, Janusz Anusiewicz (red.) Językowy obraz świata i kultura - Język a Kultura. T. 13. Wrocław: Wydawnictwo Uniwersytetu Wrocławskiego; 11-44.

Badyda, Ewa (2008) Świat barw - świat znaczeń w języku poezji Zbigniewa Herberta.

Gdańsk: Wydawnictwo Uniwersytetu Gdańskiego.

Bartmiński, Jerzy (2004) „Punkt widzenia, perspektywa, językowy obraz świata”. [W:] Jerzy

Bartmiński (red.) Językowy obraz świata. Lublin: Wydawnictwo Uniwersytetu Marii CurieSkłodowskiej; 103-120.

Bawej, Izabela (2018) Kolorowy świat w odbiorze Polaków i Niemców w szerszym kontekście językowo-kulturowym. Bydgoszcz: Wydawnictwo UKW.

Berlin, Brent, Paul Kay (1969) Basic Color Terms: Their Universality and Evolution.

Berkeley: University of California Press. Asher Nicolas, Lascarides Alex (2003) Logics of Conversation. Cambridge: Cambridge University Press.

Bogunia, Jarogniew, Elżbieta Kłoszewska (rok nieznany): Zioła - zeszyt 1. Warszawa:

Wydawnictwo „Prasa ZSL”.

Boryś, Wiesław (2005) Słownik etymologiczny języka polskiego. Kraków: Wydawnictwo

Literackie.

Chodurska, Halina (2003) Ze studiów nad fitomimami $w$ medycynie ludowej Stowian rękopiśmiennych zielników wschodniosłowiańskich XVII-XVIII wieku. Kraków: Wydawnictwo Naukowe Akademii Pedagogicznej.

Chodurska, Halina (2010) „Odcienie czerni w nazwach roślin na wschodzie słowiańszczyzny”.

[W:] Ewa Komorowska (red.) W kręgu koloru, przestrzeni i czasu. Szczecin: Uniwersytet Szczeciński; 46-58.

Duden. Das Herkunftswörterbuch. Etymologie der deutschen Sprache. (2001). Mannheim:

Dudenverlag.

Duden. Deutsches Universalwörterbuch. (2011). Dudenverlag: Mannheim, Zürich.

Duden. Die deutsche Rechtschreibung. (2001). Dudenverlag: Mannheim, Leipzig.

Goethe, Johann Wolfgang (1981): Wybór pism estetycznych. (Wybrał, opracował i wstępem poprzedził Tadeusz Namowicz). Warszawa: Państwowe Wydawnictwo Naukowe.

Gross, Rudolf ([1981] 1990) Dlaczego czerwień jest barwa miłości. [tłum. Anna Porębska] [Warum die Liebe rot ist.] Warszawa: Wydawnictwo Artystyczne i Filmowe. 
Grzegorczykowa, Renata, Waszakowa, Krystyna (2000) „O programie badań porównawczych w zakresie semantyki leksykalnej”. [W:] Renata Grzegorczykowa, Krystyna Waszakowa (red.) Studia z semantyki porównawczej. Nazwy barw nazwy wymiarów predykaty mentalne. T.1, Warszawa: Wydawnictwo Uniwersytetu Warszawskiego; 7-10.

Herder, Johann Gottfried (1951) Sämtliche Werke. Wien: J. Nadler.

Humboldt, Wilhelm von (1908/1968) Gesammelte Schriften, Tom 4. Berlin: A. Leitzmann [Behr's Verlag Photomechanischer Nachdruck. Berlin: Walter de Gruyter \& Co. [1903] Kadrič, Mira, Kaindl, Klaus, Kaiser-Cookie, Michele (2010) Translatorische Methodik. Wien: Facultas Verlag und Buchhandels AG.

Kluge, Friedrich, Seebold, Elmar (2002) Etymologisches Wörterbuch der deutschen Sprache. Berlin/New York: Walter de Gruyter.

Komorowska, Ewa (2010) Barwa w języku polskim i rosyjskim. Rozważania semantyczne.

Szczecin: Wydawnictwo Naukowe Uniwersytetu Szczecińskiego.

Kopaliński, Władysław (2015) Słownik symboli. Warszawa: Oficyna Wydawnicza Rytm. Krawczyk, Anna (1982) „Język źródłem wiedzy o człowieku”. Etnolingwistyka. T. 2; 29-38. Langenscheidts Taschenwörterbuch der polnischen und deutschen Sprache. Stanisław Walewski. (1994). Langenscheidt: Berlin, München.

Łuczyński, Edward, Maćkiewicz, Jolanta. (2002) Językoznawstwo ogólne. Wybrane zagadnienia. Gdańsk: Wydawnictwo Uniwersytetu Gdańskiego.

Mańczyk Augustyn (1982) Wspólnota językowa i jej obraz świata. Krytyczne uwagi do teorii językowej Leo Weisgerbera. Zielona Góra: Wydawnictwo Wyższej Szkoły Pedagogicznej. Meyers Grosses Handlexikon (1989). Meyers Lexikonverlag: Mannheim.

Ożarowski, Aleksander (1995): „Ziołolecznictwo”. [W:] Witold S. Gumułka, Wojciech Rewerski (red.) Encyklopedia zdrowia. T.1. Warszawa: Wydawnictwo Naukowe PWN; $467-495$.

Podręczny słownik medyczny. Polsko-niemiecki i niemiecko-polski. Małgorzata Tafil-Klawe, Jacek Klawe. (1999). Warszawa: Wydawnictwo Lekarskie. PZWL.

Podręczny słownik polsko-niemiecki. Andrzej Bzdęga, Jan Chodera, Stefan Kubica (1986). Warszawa: Państwowe Wydawnictwo, Wiedza Powszechna.

Podręczny stownik niemiecko-polski. Jan Chodera, Stefan Kubica (1979). Warszawa: Państwowe Wydawnictwo. Wiedza Powszechna.

Stanulewicz, Danuta (2006) „Zróżnicowanie regionalne prototypowych odniesień sześciu podstawowych nazw barw w języku polskim (biały, czarny, czerwony, zielony, żółty, 
niebieski) - na tle porównawczym wybranych języków słowiańskich i germańskich.” Biuletyn Polskiego Towarzystwa Językoznawczego. Nr 67; 199-211.

Teodorowicz-Hellman, Ewa (2000) „'Zielony' i 'niebieski' w języku polskim w porównaniu z 'gron' i ‘blå’ w szwedzkim”. [W:] Renata Grzegorczykowa, Krystyna Waszakowa (red.) Studia z semantyki porównawczej. Nazwy barw nazwy wymiarów predykaty mentalne. T.1, Warszawa: Wydawnictwo Uniwersytetu Warszawskiego; 73-92.

Tokarski, Ryszard (2004) Semantyka barw we wspótczesnej polszczyźnie. Lublin: Wydawnictwo Uniwersytetu Marii Curie-Skłodowskiej.

Tokarski, Ryszard (2013): Światy za słowami. Wykłady z semantyki leksykalnej. Lublin:

Wydawnictwo Uniwersytetu Marii Curie-Skłodowskiej.

Volák, Jan, Stodola, Jiří (1987): Rośliny lecznicze. Warszawa: Państwowe Wydawnictwo Rolnicze i Leśne.

Waszakowa, Krystyna (2000) „Podstawowe nazwy barw i ich prototypowe odniesienia. Metodologia opisu porównawczego". [W:] Renata Grzegorczykowa, Krystyna Waszakowa (red.) Studia z semantyki porównawczej. Nazwy barw nazwy wymiarów predykaty mentalne. T.1, Warszawa: Wydawnictwo Uniwersytetu Warszawskiego; 17-28.

Weisgerber, Leo (1953) Vom Weltbild der deutschen Sprache. T. 1, 2. Düsseldorf: Pädagogischer Verlag Schwann.

Wierzbicka, Anna (1999) Język - umyst - kultura. Wybór prac pod redakcją Jerzego Bartmińskiego. Warszawa: Wydawnictwo Naukowe PWN.

Wierzbicka, Anna (2006): Semantyka. Jednostki elementarne i uniwersalne. Lublin:

Wydawnictwo Uniwersytetu Marii Curie-Skłodowskiej.

Ziółkowska, Maria (1983): Gawędy o drzewach. - Warszawa: Ludowa Spółdzielnia Wydawnicza.

\section{Źródła internetowe:}

deutsche Suchmaschinen [on-line]

www.berliner-zeitung.de/berlin/preussisch-blau, DW 12.01.2019

www.zycieaklimat.edu.pl/Bzy, DW: 24.01.2019. 